УДК 628.74.05 DOI 10.31210/visnyk2018.03.24

(C) 2018

Прасолов С. Я., кандидат технічних наук,

Бєловол С. А., кандидат технічних наук,

Черненко Б. С., Ужищенко А. В., Шеметюк А. В., магістранти

Полтавська державна аграрна академія

\title{
ДОСЛДЖЕННЯ БЕЗПРИВОДНОГО РОТАЦІЙНОГО ОРГАНУ АДАПТЕРА ДО СІВАЛКИ ПРОСАПНИХ КУЛЬТУР
}

\section{Рецензент - доктор сільськогосподарських наук, професор П. В. Писаренко}

Представлено результати розробки безприводного ротаиійного органу адаптера до сівалки просапних культур. Проведено аналіз робочих органів грунтообробних машин; обтрунтовано трунтообробний адаптер; визначено кути афронтальності й нахилу дискового органу; проведено порівняльну оцінку показників твердості грунту; визначено рачіональні параметри і режими роботи робочого органу; визначено фракційний склад трунту та розпушення робочим органом; проведено дослідження з визначення раціонального кута ф робочого органу; встановлено поздовжній профіль насіннєвого ложа; виконано співвідношення ширини і глибини обробленої смуги; визначено коефіціснти $\kappa_{1 \text { і }} \kappa_{2}$ у формулі тягового опору безприводного ротачійного органу.

Для підвищення якості передпосівного обробітку трунту запропоновано адаптер із безприводним ротаційним органом до сівалок, який складається з поперечної балки рами, на якій розташовані секиії безприводного ротаційного органу. Для копіювання профілю поля кожна секиія забезпечена паралелограмною підвіскою і підпружиненою штангою. Крім поперечної балки рама адаптера складається з двох автозчіпок, які слугують для агрегатування з трактором, а автозчеплення з сівалкою, пов'язаних між собою поздовжніми балками. Проведено випробування результатів науково-дослідної роботи, яким підтверджено ефективність та доцільність для використання у господарстві ПП Агрофірма "Анастасія» Глобинського району Полтавської області.

Ключові слова: трунтообробна машина, стрічково-смугова обробка, безприводний ротаційний орган, охорона праиі, екологічна експертиза.

Постановка проблеми. Основне завдання агропромислового комплексу - це забезпечення потреби населення якісною, достатньої за обсягом і асортиментом продукцією 3 дотриманням вимог екологічної безпеки, енерго- та ресурсозбереження. Важливою ланкою комплексу заходів щодо підвищення родючості грунту є способи обробітку [10], які залежать від фізикомеханічних властивостей грунту, природнокліматичних умов і біологічних особливостей оброблюваних культур. Нині існують різні спо- соби передпосівного обробітку грунту, але не всі відповідають вимогам отримання сталих урожаїв культур при мінімальних енерговитратах.

Аналіз останніх досліджень і публікацій, у яких започатковано розв'язання проблеми. Ротаційні органи використовуються на одноопераційних і комбінованих машинах, що задовольняють агротехнічним вимогам $[5,6,14]$. Відомі сівалки для смугового обробітку грунту і сівби «Huard SD 300», «Fastliner 300» (400, 3000, 4000, 6000), «Fastliner SD 3000P» (SD 4000, SD 4500, 4000 SD) (Франція), СЗПП-4 (Україна), «Вікторія» і СС-6,0 (Росія) обладнані гофрованими дисками, за якими встановлені дводискові сошники [41].

Відомими $є$ комбіновані грунтообробнопосівні машини закордонного виробництва, які створені на основі одноопераційних машин, наприклад, фірма «DKL» (Великобританія) спеціалізується на виробництві широкозахватних машин. Австралійська машина має складну конструкцію і представлена рамою зі встановленими на ній послідовними рядами розпушувальних зубів, ножовими дисками, грунтообробною фрезою і сошниками сівалки. Для зниження споживаної потужності грунт обробляється по вузькій смузі без обробки міжряддя. Нарізання посівної борозни на стерньових зарубіжних сівалках супроводжується стрижневими пристосуваннями для відведення пожнивних залишків. Процес нарізання здійснюється парою нахилених дисків, методом вдавлення і бічного зсуву $[12,15,17]$. Близьким за технічною сутністю $є$ ротаційний орган сівалки прямого посіву «АМАЗОНЕ», призначений для видалення поживних рештків по ходу сошника, який складається 3 вертикальної стійки і зубчастих дисків, розташованих афронтально під кутом до вертикалі [1]. Диски входять у зачеплення один з одним на поверхні грунту і розчіпляються, зрушуючи в сторони пожнивні залишки. До недоліків належать: обмежені функціональні можливості; нездатність органу розпушувати поверхневий шар грунту; 


\section{TEХНIЧНI НАУКИ}

відсутність регулювання зубчастих дисків по кутах афронтальності і вертикального нахилу не дозволяє якісно підготувати грунт з різними фізико-механічними властивостями та робочими швидкостями руху агрегату $[17,18,20]$.

Мета досліджень: обгрунтування параметрів безприводного ротаційного органу грунтообробного адаптера до сівалок для просапних культур.

Завдання досліджень: розробка адаптера 3 безприводними ротаційними органами; визначення аналітичних залежностей і основних параметрів адаптера з безприводними ротаційними органами; проведення випробування дослідного зразка адаптера та визначення економічної ефективності використання.

Матеріали і методи досліджень. Для вирішення поставленої мети був виготовлений безприводний ротаційний орган. Застосування двох регульованих афронтальних голчастих дисків повинно забезпечувати достатній ступінь розпушування дна борозни і нижньої частини гребеня.

Для підвищення якості передпосівного обробітку грунту пропонується адаптер із безприводним ротаційним органом до сівалок. Він складається 3 поперечної балки рами адаптера 1, на якій за допомогою кронштейнів 5 розташовані секції безприводного ротаційного органу 8. Для копіювання профілю поля кожна секція забезпечена паралелограмною підвіскою 6 і підпружиненою штангою 7. Крім поперечної балки рама адаптера складається 3 двох автозчіпок 2 і 4, пов'язаних між собою поздовжніми балками 3. Автозчіпка 2 слугує для агрегатування з трактором, а автозчеплення 4 - з сівалкою 10.

Підвищення якості при смуговому передпосівному обробітку грунту досягається за рахунок застосування безприводного ротаційного органу (рис. 1).

Робочий орган складається 3 вертикальної стійки 1 зі змонтованою поперечною віссю 2.
До вісі приварені дві цапфи 3 і 4, симетрично вигнуті на кут $\varphi$. На цапфи встановлені два голчастих диска 5 і 6.

Для контролю установки заданого кута ф повороту вісі 2 призначені кутомірна шкала 7, змонтована на стійці 1, і покажчик 8, встановлений на вісі 2 . Для фіксації вісі 2 на стійці 1 передбачений стопорний болт 9. Голки дисків 5 і 6 центруються у взаємних просторах за рахунок радіального звуження від периферії до центру.

Площини кочення голчастих дисків перетинаються в зоні взаємодії з грунтом.

Якість обробітку грунту досягається за рахунок руйнування грунтової кірки і грудок локальною дією наконечників голок по краях оброблюваної смуги і виникаючими деформаціями зсуву в зоні при подальшому русі голок у взаємно протилежних напрямках. Мінімальна лінійна швидкість руху голок в зоні взаємодії з грунтом виключає розпушування і сприяє значному збільшенню поступальної швидкості агрегату. Голки дисків очищаються від пожнивних залишків за рахунок відцентрової сили на верхній дузі траєкторії руху по циклоїді, де голки рухаються 3 максимальною лінійною швидкістю.

На рисунку 2 представлений графік, отриманий вимірювальним комплексом у польових умовах. В дослідах визначалися показники безприводного ротаційного органу та враховувалися агрофон, твердість грунту в оброблюваному шарі, вологість грунту, справжня глибина ходу та робоча швидкість агрегату.

На твердограмі вказувалося місце вимірювання, дата і час та дані налаштувань безприводного ротаційного органу. Результати вимірювань твердості на ділянці, обробленої безприводним ротаційним органом, порівнювалися 3 твердістю грунту, обробленого культиватором 3 універсальними стрілчастими лапами.

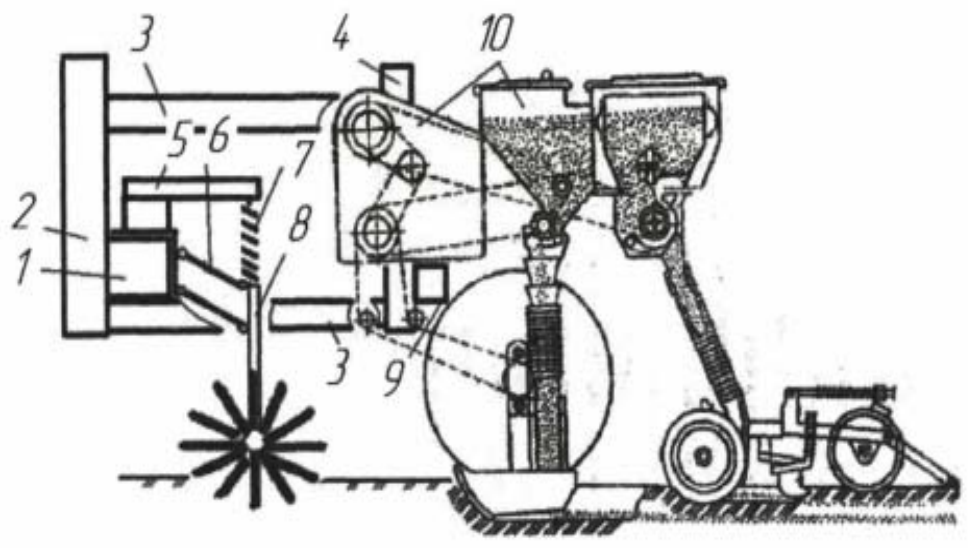

Рис. 1. Адаптер з безприводним ротаційним органом і сівалкою СО-4,2 


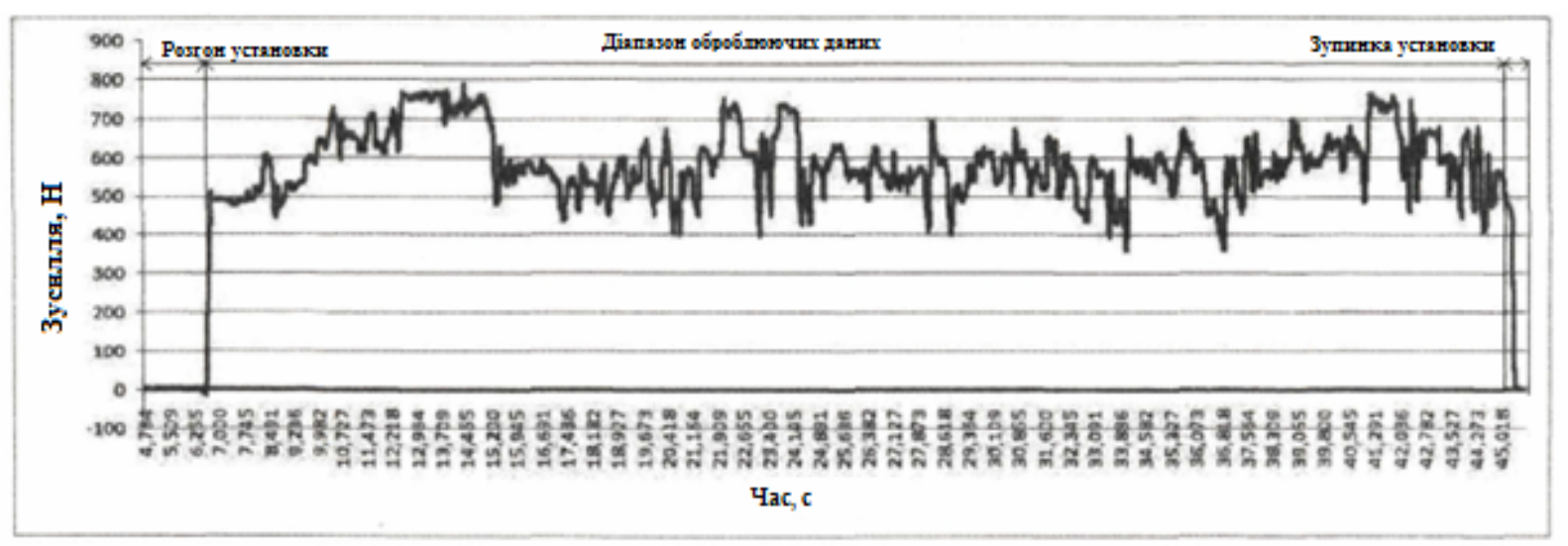

Рис. 2. Графік робочої діаграми

Вимірювання вологості грунту проводилися на ділянці перед початком і в кінці кожного циклу польових випробувань згідно стандарту. Проби грунту для визначення вологості взяті з середньої глибини обробки за допомогою бурапробовідбірника. За попередніми дослідженнями встановлено, що безприводний ротаційний орган залишає мікробороздку і мікрогребінь по обидві сторони сліду [2]. Таким чином, для визначення дійсної глибини ходу необхідно попередньо встановити безприводний ротаційний орган на визначену глибину. Вимірювання глибини ходу органу і глибини обробленого шару виконувалося в п'яти точках. Поздовжній профіль утвореної борозни впливає на якість посіву дрібнонасінних культур - моркви, цибулі. Чим рівніше поздовжній профіль, тим якісніше сівба, стабільніша глибина сівби і менший знос підвіски сошникової групи сівалки.

Поздовжнє профілювання визначалося на кожній ділянці. Перед проходом агрегату були вбиті дві опорні стійки за напрямку руху, на які встановлювалася координатна рейка, горизонтальність якої перевірялася за допомогою будівельного рівня. Відстань від поверхні поля до верхньої сторони рейки вимірювали лінійкою і знімали поздовжній профіль до проходу агрегату. Далі робились відмітки на допоміжній і поперечній рейках і після проходу машини їх повертали в вихідне положення, знімали профіль дна обробленої полоси по довжині координатної рейки. При цьому виступаючі на поверхню грунту частини кореневих систем попередників і залишків стерні до уваги не бралися [3]. При визначенні поздовжнього профілю вимірювалась і ширина борозни по тріщинах країв за шкалою рейки i результати заносилися в таблицю для подальшої обробки.
Ступінь кришення грунту в зоні обробки безприводного ротаційного органу визначався за поділками приладу взятої проби на фракції. Числові інтервали розмірів частинок вибиралися, виходячи 3 агротехнічних вимог, згідно з якими не менше 80 \% грунтових частинок повинні мати розміри не більше 25 мм при мінімальній кількості пилоподібних частинок розмірами менше 1,0 мм [9]. Проби грунту з обробленої зони безприводним ротаційним органом бралися за допомогою совка, з вилученням розпушування шару на ділянці довжиною 15-20 см. Інтервал взяття проб - 2,0-2,5 м, рівномірний по довжині борозни [4]. Щоб уникнути додаткового дроблення проби грунту пропускалися через набір решіт із розмірами отворів $25 \times 25$ мм, діаметром $10,5,2,5$ та 1,0 мм $[17,18,20]$.

Попередні кінематичні дослідження безприводного ротаційного органу на дослідній рамі культиватора показали, що конструкція зі шкалою і покажчиком на цапфі і стійці не виправдовує призначення. Тому в ході подальших досліджень відмовилися від цього вузла. Установка кута афронтальності $\varphi$ проводилося за допомогою будівельного рівня і кутомірної функції сучасного смартфону «Nokia». Визначення швидкості агрегату проводилося виміром пройденого шляху на довжині гону і діленням на час проходу. Довжина гону визначалася шляхом: використання функціi GPS-навігатора, встановленого на смартфоні «Nokia». Вимірювання часу при дослідженні кінематичних і агротехнічних показників проводилися секундоміром. Значення часу при визначенні тягового опору автоматично фіксуються на комп'ютері.

Результати досліджень. Основним критерієм якості виконання предпосівної обробки грунту безприводним ротаційним органом i універса- 


\section{TEХНІЧНI НАУКИ}

льною стрілчастою лапою була прийнята твердість грунту, що визначається за стандартною методикою [13].

Дослідження твердості грунту проводилися до і після відвальної оранки стерньового агрофона. Вологість грунту на ділянці становила $\omega_{\alpha}=18 \pm$ $2,0 \%$, за твердості окремих грудок до $\mathrm{p}=3,50$ МПа на ріллі. Для досліду використовувались голчасті диски $\mathrm{R}_{1}=\mathrm{R}_{2}=0,19$ м із кількістю голок на диску $n_{1}=n_{2}=12$. Кути $\varphi=45^{\circ}$ i $\theta=17^{\circ}$ не змінювалися. Ширина обробітку: мінімальна - при $\varphi=90^{\circ}$, до 6,0 см; максимальна - при $\varphi=$ $0^{\circ}$, до 14,0 см ; діаметр голок - 12 мм; форма голок - радіальна; форма ріжучого леза голок: а) конусна, загострена, б) скошена, самозагострювальна; діапазон регулювання кута $\varphi-0-360^{\circ}$; висота стійки - 330 мм; перетин стійки - 16 х 45; маса $-6,4$ кг [16].

Робоча швидкість на ріллі при культивації дорівнює $\mathrm{v}_{\mathrm{M}}=1,21 \mathrm{M} / \mathrm{c}$, при обробці безприводним ротаційним органом $\mathrm{v}_{\mathrm{M}}=1,52 \mathrm{M} / \mathrm{c}$, на стерньовому агрофоні - 1,39 м/с і 1,56 м/с відповідно. Дослідження показали, що за первісної твердості грунту 1,43 МПа після обробки безприводним ротаційним органом на оброблюваній смузі знизилася до 0,38-0,43 МПа на глибині ходу робочих органів 5,5-6,0 см. Твердість грунту після одноразової та двократної культивації на глибину до 8,5-9,0 см склала 0,4-0,48 МПа та 0,280,36 МПа. На ріллі твердістю 1,12-1,15 МПа показники наступні: твердість після обробки безприводним ротаційним органом дорівнює 0,330,35 МПа, після 1-го проходу культиватора 0,34-0,37 МПа (рис. 3) і 0,18-0,26 МПа - після 2го проходу (рис. 4). Середня твердість обробленого безприводним ротаційним органом пласта менша, ніж після одноразової культивації універсальними стрілчастими лапами, але більше твердості пласта після двократної культивації $[17,18,20]$. Встановлена залежність ступеня заглиблення робочих органів від твердості грунту: глибина ходу безприводного ротаційного органу на стерні агрофону склала 6,5 см, на ріллі 10,0 см (рис. 5), а робочих органів культиватора $-9,0$ і 13,0 см (рис. 6).

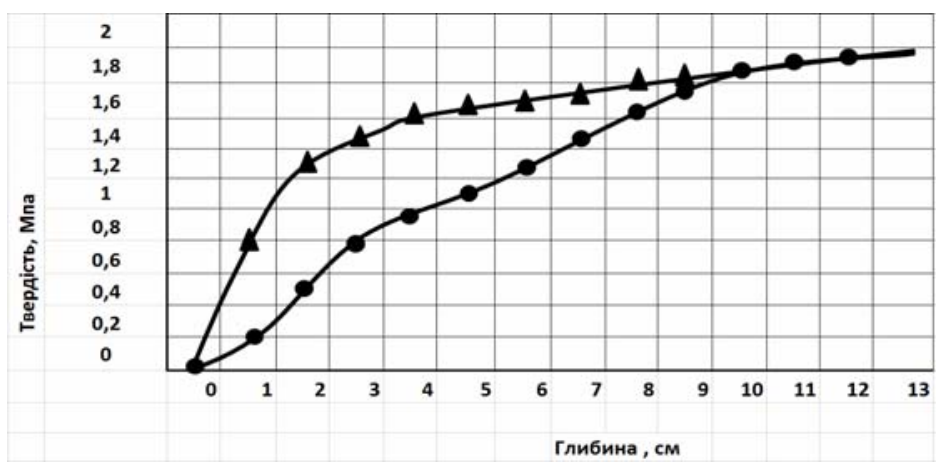

Рис. 3. Порівняння твердості трунту до і після обробки безприводним ротаційним органом (агрофон-стерня ячменю)

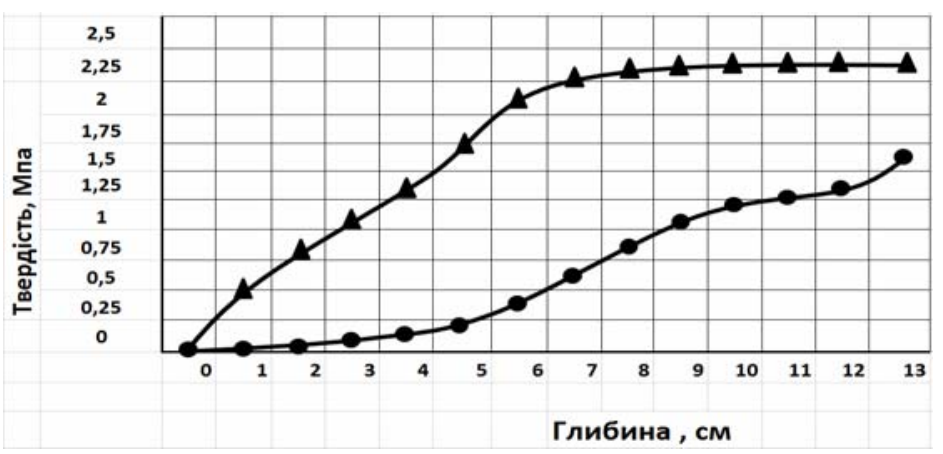

Рис. 4. Порівняння твердості трунту до і після 2-кратної культивації універсальної стрілчастої лапою (агрофон - стерня ячменю) 


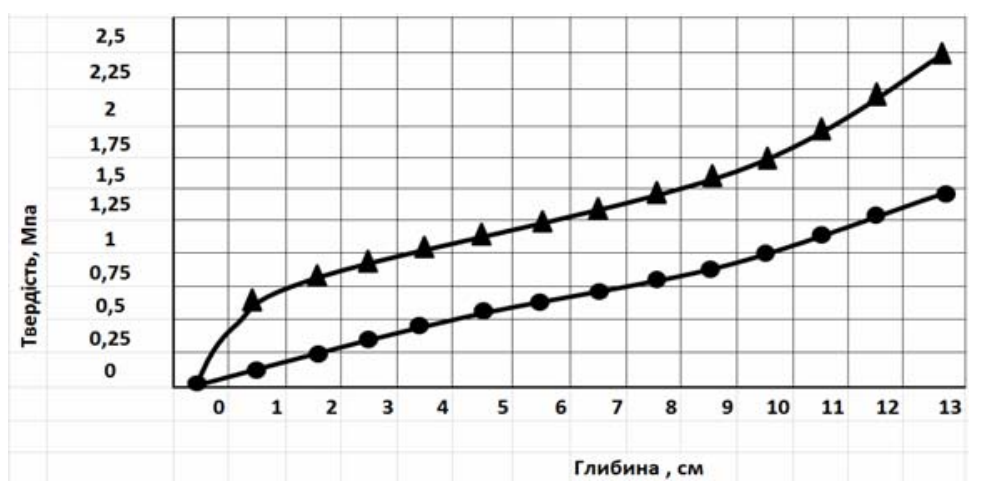

Рис. 5. Порівняння твердості трунту до і після обробітку безприводним ротаційним органом (агрофон - рілля)

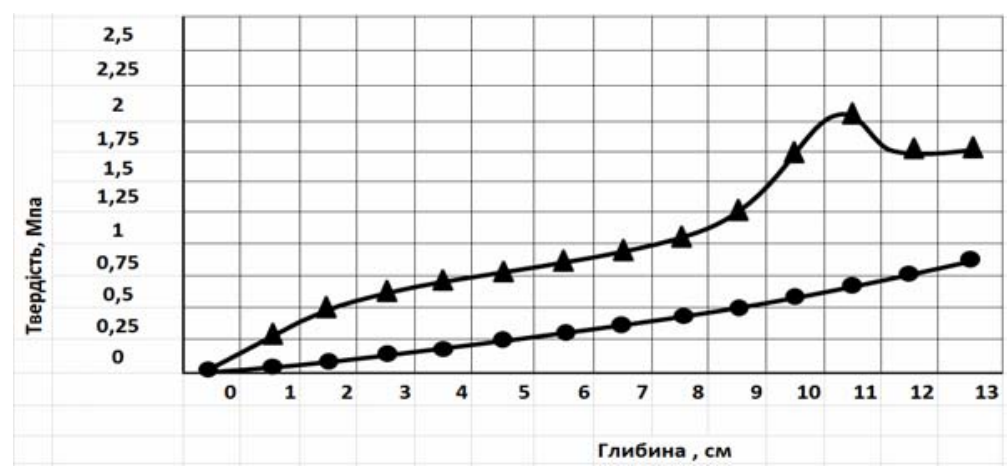

Рис. 6. Порівняння твердості трунту до і після обробітку двократної культивації універсальною стрілчатою лапою (агрофон - рілля)

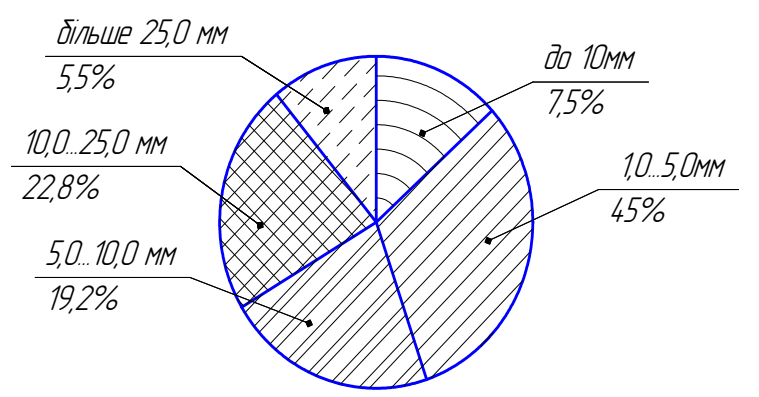

\section{Рис. 7. Усереднений агрегатний склад трунту, обробленої безприводним ротаційним органом} (агрофон-стерня ячменю)

За результатами дослідження встановлено, що збільшення кількості голок на дисках сприяє інтенсивному кришенню грунту. Випробування безприводного ротаційного органу 3 кришіння грунту проводились за вологості $\omega_{\alpha}=22,1 \%$, твердості $P=1,47$ МПа і глибини $0-10$ см на ріллі. Встановлено, що обробка безприводним ротаційним органом стерньового агрофона найцінніша для посіву дрібнонасінних культур: моркви, редиски - фракція від 1,0 до 10,0 мм становить $65 \%$, для крупнонасіннєвих просапних культур фракція 1,0 до 25,0 мм дорівнюе 88$90 \%$. Ерозійно-небезпечна пиловидна фракція розміром менше 1,0 мм в обробленої стерні не перевищує 7,5\% [18].

За результатами дослідів на ріллі встановлено, що за обробки безприводним ротаційним органом спостерігається інтенсивне подрібнення грудок розміром більше 10 мм на фракції 1,0-5,0 мм i 5,0-10,0 мм - зниження з 68,3 до 4,7 \% (рис. 7 ). 3а таким переходом агротехнічна фракція розміром 1,0-10 мм після обробки склала 85-86\%. Високі значення коефіцієнта варіації (78,66 і 26,1\%) фракції 25,0 мм і більш на досліджуваних пробах в обох випадках вказують на зворотне скочування в незруйнованих грудок в утворену борозну. 3 урахуванням наявності спеціальних грудковідвідників перед сошниками просапних сівалок, забезпечує приблизно п'ятивідсотковий вміст великої фракції в розпушеній безприводним ротаційним органом смузі, що вважається допустимим. 


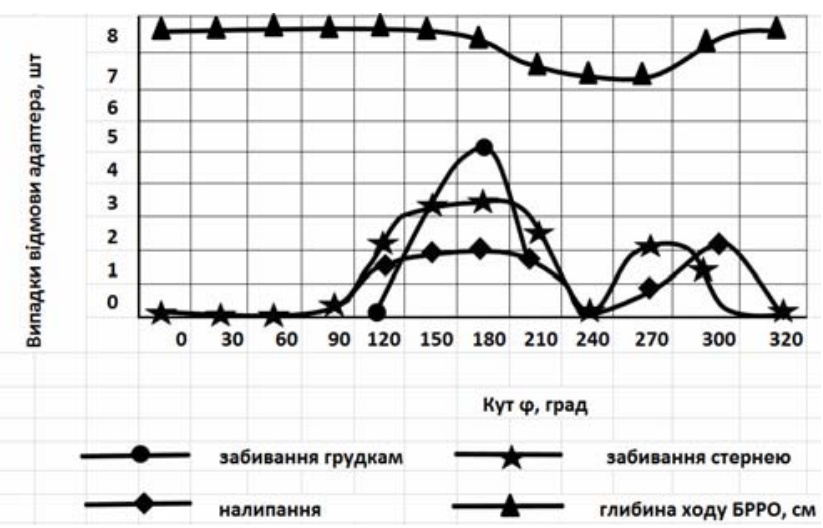

Рис. 8. Діаграми відмов і глибини ходу безприводного ротаційного органу

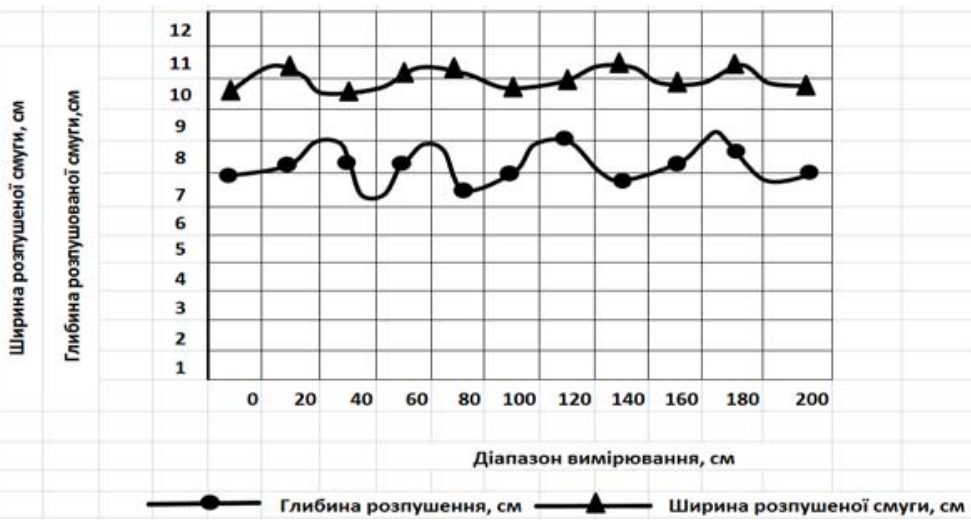

Рис. 9. Поздовжниій профіль оброблюваної смуги за $\varphi=20^{\circ}, \theta=17^{0}, v=1,93 \mathrm{M} / \mathrm{c}$

Оскільки на безприводному ротаційному органі є можливість регулювання кута афронтальності $\varphi$ в межах від 0 до $360^{\circ}$, то одним із завдань досліджень було визначення раціонального робочого кута $\varphi$. Для цього на довжині гону 100 м визначалися забиття і залипання безприводного ротаційного органу пожнивними залишками, стернею та проводилася перевірка виконання агротехнічних показників після обробки ділянки. Для забезпечення можливості регулювання кута $\varphi$ в діапазоні $240-300^{\circ}$ була виготовлена дослідна Г-подібна стійка.

Дослідженнями встановлено, що задана глибина ходу безприводного ротаційного органу досягається в певних режимах. Отримані дані показали, що в діапазоні кута $\varphi=0-90^{\circ}$ число відмов дорівнює 0. У діапазоні кута $\varphi=120$ $210^{\circ}$ виникають часті відмови безприводного ротаційного органу через забивання міждискової зони стернею, пожнивними залишками. При куті $\varphi=210-330^{\circ}$ спостерігається нестабільний хід безприводного ротаційного органу по глибині 3 частковим заглибленням і утворюються дві розпушені смуги 3 недостатнім дотриманням агротехнічних показників через відсутність защемленного зсуву грунту між голками безпри- водного ротаційного органу (рис. 8).

Оптимальною робочою зоною установки кута $\varphi$ вважається діапазон від 0 до $90^{\circ}$, а число відмов $=0$, тому подальші практичні дослідження безприводного ротаційного органу були проведені в даному діапазоні $[7,8]$.

Для перевірки якості поздовжнього профілю утвореної безприводним ротаційним органом борозни визначалась відстань від рейки $з$ відмітками через кожні $10 \mathrm{~cm}$ до поверхні поля і дна борозни, також були отримані дані ширини борозни за різних кутів установки $\varphi$ (рис. 9). При цьому кут вигину цапфи $\theta$ залишався незмінним і дорівнює $17^{\circ}$. Досліди проводилися за середньої швидкості $\mathrm{v}=1,9$ м/с. Аналіз досліджень показав, що: зміна кута $\varphi$ в межах визначеного робочого діапазону не робить впливу на поздовжню гребінчастість поверхні і дно обробленого пласта; за $\varphi=0^{\circ}$ розкид значень ширини борозни найбільший.

Співвідношення ширини і глибини обробленої смуги записуються функцією $A=f_{l}(\varphi)$, а утвореної борозни $A_{1}=f_{2}(\varphi)[11,16]$. Розташування осей координат передбачається по осі симетрії борозни і обробленої смуги, то постійний коефіцієнт В дорівнюватиме нулю. Дані отримані в ході дослідів з визначення розмірів перетину обробленої смуги i 


\section{TEХНIЧНI НАУКИ}

утвореної борозни за різних кутів установки $\varphi$. Аналіз отриманих даних показав наступне:

1) коефіцієнт варіації поперечного перерізу розпушеної смуги при $\varphi=90^{\circ} \mathrm{v}=55,45 \%$, це пов'язано 3 тим, що ширина борозни невелика i за малих швидкостей до $1,5 \mathrm{~m} / \mathrm{c}$ спостерігається зворотне скочування великих грудок грунту назад у борозну;

2) ширина борозни знаходиться в межах за $\varphi=$ 0-30 в прямій залежності від гребінчастого обробітку;

3) збільшення поступальної швидкості агрегату збільшує ширину і глибину борозни і зменшує глибину обробленої смуги, за $\varphi=0-30^{\circ}$;

4) коефіцієнти $\mathrm{A}$ i $\mathrm{A}_{1}$ показують, що за збільшення кута $\varphi$ від 0 до $90^{\circ}$ збільшується ширина борозни і обробленої смуги; з високою вірогідністю 98,2 і 97,0 \% описуються квадратичним рівнянням $\mathrm{y}=0,0099 \mathrm{x}^{2}-0,250 \mathrm{x}+0,257 \mathrm{i} \mathrm{y}=$ $-0,018 \mathrm{x}^{2}+0,13 \mathrm{x}-0,083$;

$5)$ глибина борозни за будь-яких значень $\varphi$ коливається в межах 3,0-4,0 см.

Аналіз отриманих результатів показує, що в робочій зоні кута $\varphi=0-90^{\circ}$ тяговий опір буде найменшим за виставлення кута $\varphi=45^{\circ}$. При вимірах коефіцієнт варіації швидкості не перевищив діапазон значень 0-10\%. Для визначення тягового опору безприводного ротаційного органу проводились досліди на ріллі і на стерньовому агрофоні.

Висновки. Результати проведених досліджень підтверджують доцільність застосування запропонованого безприводного ротаційного органу адаптера до сівалки просапних культур, адже був обгрунтуваний грунтообробний адаптер з безприводним ротаційним органом; визначено кути афронтальності $\alpha=(6-16)$ і нахилу дискового органу $\beta=(1-135)$; встановлено кінематичні пара-

\section{БІБЛІОГРАФІЯ}

1. Amazone. D9-AD3. AmazonevJWerke $\mathrm{H}$. Drewer GmbH@Co. KG.Postfach51.

2. Браженко C. A., Пастухов B. I. Обробка міжрядь просапних культур ротаційним робочим органом // Збірник наукових праць Вінницького національного аграрного університету. Серія «Технічні науки». - Вінниця, 2012. - Вип. 11, Т. 1(65). - C. 178-181.

3. Буга В. Г. Ленточно-бороздковый посев сои // Механизация и электрификация сельского хозяйства. - 1990. - №4. - С. 19-20.

4. Бахтин П. У. Физико-механические и технологические свойства почв. - М. : Знание, 1971. 64 с.

5. Вагин А. Т., Белевич П. К., Пилецкий А. 3., Емец H. A. Игольчатый диск для противоэрозионной обработки почв // Механизация и электрификация метри плоского афронтального і нахиленого дисків; визначено параметри безприводного ротаційного органу; встановлено параметри грунтообробного адаптера до основних типів сівалок для просапних культур; визначено площі зсуву і відкидання грунту безприводним ротаційним органом; обгрунтувано теоретичну тягу опору безприводного ротаційного органу і раціональні кути $\varphi$ $=(0-360), \beta, \theta=17^{\circ}$ i $\alpha$ робочого органу. Сукупність встановлених ознак забезпечує ефективність безприводного ротаційного органу для підготовки грунту під смуговий посів та дозволяють визначити траєкторії і швидкості руху ротора, необхідні для обгрунтування і вибору основних конструктивних параметрів диска.

Перевагою даного способу передпосівної підготовки грунту є один тип тягового засобу, що знижує витрати на технічне обслуговування i ремонт.

Застосування безприводного ротаційного органу, в порівнянні 3 традиційними способами передпосівної підготовки грунту, зменшує витрати палива 31 га площі посіву просапних культур до 12,5 кг, передбачає зниження втрат врожайності за рахунок своєчасного виконання польових робіт.

Річний прибуток від експлуатації запропонованого безприводного ротаційного органу складає 54038 грн, а термін окупності - протягом року. Річний економічний ефект від підвищення продуктивності становить 39768 грн.

Проведено випробування результатів науководослідної роботи, яким підтверджено ефективність та доцільним для використання запропонованого безприводного ротаційного органу у господарстві ПП Агрофірма «Анастасія» Глобинського району Полтавської області.

сельского хозяйства. - 1975. - №5. - С. 7-9.

6. Комбинированные почвообрабатывающие машины / А. А. Вильде, Ф. Х. Цесниекс, Ю. П. Моритис [и др.]. - Ленинград : Агропромиздат. Ленингр. отд-ние, 1986. - 128 с.

7. Випробування сільськогосподарської техніки. Машини i знаряддя для обробітку грунту: СОУ 74.3-37-155:2004. Офіц. вид. Київ : М-во аграрної політики України, 2006. 104 с. (Нормативний документ Мінагрополітики України. Методи випробувань).

8. Заїка П. М. Теорія сільськогосподарських машин. - Т.1. Ч.1. Машини та знаряддя для обробітку грунту. - Харків : ОКО, 2001. - 444 с.

9. Замойська $K$. B. Вплив фізико-механічних властивостей грунту на якість роботи роторного 


\section{TEХНІЧНІ НАУКИ}

культиватора // Збірник наукових праць Подільського державного аграрно-технічного університету. - Вип. 13. - Кам'янець-Подільський : Абетка, 2005. - С. 475-478.

10. Зубеиь М. В., Гуков Я. С., Грициишин М. I. Актуальні проблеми технічної політики в аграрному секторі України. - К. : ДІА, 2007. - 80 с.

11. Конищев A. A. Исследование механики взаимодействия игольчатых дисков с почвой // Динамика почвообрабатывающих агрегатов и рабочие органы для обработки почвы. - Научные труды ЧИМЭСХ. - Челябинск, ЧИМЭСХ, 1982. - С. 51-56.

12. Макаров П. И. Технология и техника для гладкой вспашки почв. - Казань : изд-во Казан. Университета, 2000. - 208 с.

13. Машини для обробітку грунту і сівби / за ред. Кравчука В. І., Мельника Ю. Ф. - Дослідницьке : УкрНДІПВТ ім. Л. Погорілого, 2009. - 288 с.

14. Пастухов В. I., Браженко С. А. Експериментальне обгрунтування параметрів ротаційного робочого органу культиватора // Науковий вісник Луганського національного аграрного університету. Серія «Технічні науки». - Луганськ : Видавництво ЛНАУ, 2011. - Вип. 30. С. 175-182.

15. Панов И. М., Ветохин В. И. Современное состояние и перспективы развития земледельческой механики в свете трудов В. П. Горячкина // Вестник МГАУ. Серия «Агроинженерия». -

\section{ANNOTATION}

Prasolov Ye. Ya., Belovol S. A., Chernenko B. S., Uzhyshchenko A. V., Shametiuk A. V. Investigation of the free driving rotational body of the adaptor to the root of prosapic cultures.

The article presents the results of the development of a non-rotating rotational organ of the soil-working adapter to a seed drill of cultivating crops. The analysis of working bodies of soil-working machines was carried out; the constructive-technological scheme of the soilworking adapter is substantiated; defined angles of inclination and inclination of the disc body; comparative estimation of soil hardness indexes; defined rational parameters and operating modes of the working body; determined fractional composition of soil and loosening by the working body; researches have been conducted to determine the rational angle $\varphi$ of the working organ; the longitudinal profile of the seed bed is established; the ratio of the width and depth of the treated strip is executed; the coefficients $\mathrm{k}_{1}$ and $\mathrm{k}_{2}$ in the formula of the traction resistance of the non-driven rotational body are determined.

To improve the quality of pre-sowing soil cultivation,
2008. - №2 (27). - С. 9-14.

16. Путрин A. C. Оптимальные параметры игольчатых ротационных рабочих органов // Тракторы и сельскохозяйственные машины. 2002. - №8. - С. 16-19.

17. Пат. 2399178. Российская Федерация, МПК AO 1B 21/04. Ротационное почвообрабатывающее орудие / П. А. Смирнов, И. И. Максимов, М. П. Смирнов, А. В. Кудряшов. № $2009104182 / 21$; заявл. 09.02.2009; опубл. 20.09.2010, Бюл. № 26. 5 c.

18. Пат. 2400034. Российская Федерация, МПК АO 1B 23/06. Почвообрабатывающее орудие с игольчатыми дисками / П.А. Смирнов, М. П. Смирнов. № 2008152889/21; заявл. 30.12.2008 ; опубл. 27.09.2010. Бюл №27. 6 с.

19. Сільськогосподарська техніка. Методи економічного оцінювання техніки на етапі випробувань : ДСТУ 4397:2005. - [Чинний від 2005-04-28]. Київ : Держспоживстандарт України, 2005. 16 с. (Національний стандарт України).

20. Смирнов М. П., Максимов И. И. Анализ работы ротационных игольчатых дисков для междурядной обработки картофеля //Актуальные вопросы совершенствования технологии производства и переработки продукции сельского хозяйства : Мосоловские чтения посвящаются 120-летию со дня рождения академика В. П. Мосолова : мат. междунар. науч.-практ. конф. - Вып. Х. - Йошкар-Ола, 2008. - С. 362.

an adapter with a rotary rotary device to the seeders is proposed. It consists of a transverse beam of a frame, on which, with the help of brackets, there are sections of a non-rotating rotary body.

To improve the quality of pre-sowing soil cultivation, an adapter with a rotary device to the seeders is offered. It consists of a transverse beam of a frame, on which, with the help of brackets, there are sections of a non-rotating rotary body. To copy the field profile, each section is provided with a parallelogram suspension and a spring-loaded rod. In addition to the transverse beam of the adapter frame consists of two auto-scraps, which serve for aggregating with the tractor, and auto-coupling with a drill, connected by a longitudinal beam. The testing of research results has been carried out, which confirms the efficiency and expediency for use in the farm of the PP agricultural firm «Anastasia» in Globyno district, Poltava region.

Key words: greenhouse machine, roll-treatment processing, free rolling organ, labor protection, environmental expertise. 